bioRxiv preprint doi: https://doi.org/10.1101/2020.08.03.234856; this version posted August 4, 2020. The copyright holder for this preprint (which was not certified by peer review) is the author/funder, who has granted bioRxiv a license to display the preprint in perpetuity. It is made available under aCC-BY-NC-ND 4.0 International license.

Beecraft and Rooney. 2020. Bioconcentration of glyphosate in wetland biofilms. PREPRINT. Contact rrooney@uwaterloo.ca

\title{
1 Bioconcentration of glyphosate in wetland biofilms
}

3 Laura Beecraft ${ }^{\text {a }}$

4 1njbeecr@uwaterloo.ca

5

6 Rebecca Rooney ${ }^{a^{*}}$

7 rebecca.rooney@uwaterloo.ca

$8 \quad$ * Corresponding author

9

$10{ }^{a}$ Department of Biology, University of Waterloo

11200 University Ave. W.

12 Waterloo ON N2L 3G1

13

14 
Beecraft and Rooney. 2020. Bioconcentration of glyphosate in wetland biofilms. PREPRINT. Contact rrooney@uwaterloo.ca

\section{Abstract}

Wetland biofilms were exposed to the herbicide glyphosate via in situ field exposures and controlled microcosm experiments to measure bioconcentration and metabolism of glyphosate by biofilm organisms. Glyphosate concentrations in biofilms were orders of magnitude higher than the surrounding water, bioconcentration factors averaged 835 and 199 in field- and lab-exposed biofilms, respectively. Glyphosate in water where it had been detected in biofilms at fieldexposed sites ranged from below detection $(<0.001 \mathrm{ppm})$ up to $0.13 \mathrm{ppm}$. Glyphosate bioconcentration in biofilms was inversely proportional to levels in the surrounding water, and the retention kinetics were similar to both adsorption and enzymatic models. Microorganisms

24 present in both the water and biofilms metabolized glyphosate to its primary breakdown product aminomethyl phosphonic acid (AMPA), with increased rates of breakdown in and around the biofilms. Photosynthetic efficiency of the algae within the biofilms was not affected by $24 \mathrm{~h}$

27 glyphosate controlled exposures. Our results demonstrate the role of biofilms in improving wetland water quality by removing contaminants like glyphosate, but also as a potential exposure route to higher trophic levels via consumption. Due to bioconcentration of pesticides, exposure risk to organisms consuming or living in biofilms may be much higher than indicated by concentrations in ambient water samples. herbicide 
Beecraft and Rooney. 2020. Bioconcentration of glyphosate in wetland biofilms. PREPRINT. Contact rrooney@uwaterloo.ca

37 Since its introduction in 1974, use of the systemic, broad-spectrum herbicide glyphosate [N(phosphonomethyl)glycine] has expanded dramatically in agriculture, silviculture, and the management of invasive plants (e.g. Annett et al., 2014; Breckels and Kilgour, 2018). Over 8.6 billion $\mathrm{kg}$ of the active ingredient has been applied worldwide, making glyphosate the most heavily used herbicide globally (Benbrook, 2016). Its enthusiastic adoption is attributed in part to the advent of transgenic, glyphosate resistant crops in the mid-1990s and the establishment of an

43 inexpensive generic supply following Monsanto’s US patent expiry (Duke and Powles, 2008).

44 Growing glyphosate use is also attributed to the development of glyphosate resistant weeds and its increasing application as a crop desiccant (Myers et al., 2016). As a result of its widespread use, glyphosate has become a ubiquitous contaminant in aquatic ecosystems (Battaglin et al., 2014; Carles et al., 2019; Lupi et al., 2019; Majewski et al., 2014; Medalie et al., 2020; MontielLeón et al., 2019). synthase (EPSPS), which blocks the shikimic acid pathway for aromatic amino acid synthesis in plants and susceptible microorganisms, including some bacteria and microalgae (Amrhein et al., 1980; Solomon and Thompson, 2003). Because the shikimic acid pathway is absent in animals

53 (Starcevic et al., 2008), glyphosate is considered a low toxicity risk to non-target biota [e.g.

55 ((WHO), 2005; Giesy et al., 2000). Glyphosate is highly soluble in water (water solubility = $56 \quad 10,000-15,700 \square \mathrm{mg} \cdot \mathrm{L}^{-1}$ at $25 \square^{\circ} \mathrm{C}$; (Annett et al., 2014)), has a low octanol-water partition

57 coefficient $\left(\log \mathrm{K}_{\mathrm{ow}}=-3.2\right.$; (Henderson et al., 2010)), adsorbs strongly to soil and sediment (soil 58 adsorption coefficient $=24,000 \square \mathrm{L}^{\mathrm{kg}} \mathrm{kg}^{-1}$; (Annett et al., 2014)), and can be rapidly broken down 
Beecraft and Rooney. 2020. Bioconcentration of glyphosate in wetland biofilms. PREPRINT. Contact rrooney@uwaterloo.ca

by microbial degradation (Silva et al., 2018; Solomon and Thompson, 2003). These factors

60

61

62 contribute to a relatively short but variable half-life in water (1-91 days) (Hébert et al., 2019), and the expectation that glyphosate is rapidly dissipated from aquatic environments, with low likelihood of bioaccumulation, and minimal risk to aquatic biota (Breckels and Kilgour, 2018; Siemering et al., 2008; Solomon and Thompson, 2003).

Paradoxically, despite consistent findings of low toxicity to animals from ecotoxicology studies (Annett et al., 2014; Breckels and Kilgour, 2018; Giesy et al., 2000; Solomon and Thompson, 2003), some studies suggest that even low glyphosate concentrations may cause disruption of endocrine systems, hepatorenal damage, birth defects, teratogenic effects and alterations of the microbiome in mammals and insects (reviewed in Myers et al., 2016). Glyphosate has been shown to alter algal and bacterial abundance (Berman et al., 2020; Pizarro et al., 2016) and composition (Pérez et al., 2017; Smedbol et al., 2018) in both plankton and biofilm communities (Janßen et al., 2019; Kish, 2006; Vera et al., 2010), and it is now being recognized as a possible agent of eutrophication (Hébert et al., 2019). This is because the microbial breakdown of glyphosate releases bioavailable phosphorus (e.g. Carles et al., 2019), favoring microbes that can degrade glyphosate under low phosphorus conditions (Berman et al., 2020).

What can explain this paradox? Ecotoxicological studies of glyphosate face a variety of limitations (reviewed in Annett et al., 2014)(Annett et al., 2014). Notably, most ecotoxicology research examining the effects of glyphosate on aquatic organisms focuses on direct exposure through immersion in glyphosate contaminated water, but there may be other ecologically significant exposure pathways. For example, glyphosate adsorbs to sediment and can be taken up by both bacterial and algal cells (Forlani et al., 2008; Sviridov et al., 2015; S. Wang et al., 2016), 
Beecraft and Rooney. 2020. Bioconcentration of glyphosate in wetland biofilms. PREPRINT. Contact rrooney@uwaterloo.ca

82 including active and passive uptake pathways for biofilms (Battin et al., 2016). Biofilms are

83 complex communities including bacteria, archaea, algae, viruses, fungi and protists living at the

84 interface of substrates and the surrounding water (Battin et al., 2016; Besemer, 2015; Cui et al.,

85 2017). The sediment and fine particles that collect in biofilms, the complex and often

86 polyanionic nature of their exopolysaccharides, and the high-water content (Chaumet et al.,

87 2019; Sutherland, 2001) may facilitate glyphosate bioconcentration in biofilms despite its low

88 octanol-water partition coefficient and high water solubility. Recently, Fernandes et al. (2019)

89 demonstrated that river biofilms in Brazil are capable of taking up glyphosate, and Klátyik et al.

90 (2017) and Carles et al. (2019) confirmed through microcosm studies that river biofilms are

91 capable of breaking it down. Rooney et al. (2020) observed that wetland biofilms can

92 bioconcentrate a diverse array of agrochemicals at concentrations much higher than the

93 surrounding ambient water. However, glyphosate was not among the pesticides examined in that

94 study. If biofilms are bioconcentrating glyphosate from the ambient environment, biofilm grazers

95 like invertebrates, snails, tadpoles and fish larvae might be exposed to higher concentrations of glyphosate than anticipated from water quality monitoring.

To establish whether wetland biofilms were bioconcentrating glyphosate, we employed a combination of field and controlled dose-response laboratory experiments. Our first objective was to determine the relationship between exposure dose and bioconcentration of glyphosate in wetland biofilms. In particular, we aim to test the hypothesis that if glyphosate is bioconcentrating in wetland biofilms, it is through an adsorption mechanism that would fit a

102 saturation model. Our second objective was to assess whether wetland biofilms (i.e. the

103 microorganisms within them) were metabolizing glyphosate to yield glyoxylate and

104 aminomethyl-phosphonic acid (AMPA) (Sviridov et al., 2015), leading to the accumulation of 
Beecraft and Rooney. 2020. Bioconcentration of glyphosate in wetland biofilms. PREPRINT. Contact rrooney@uwaterloo.ca

105

106

107

108

109

AMPA in biofilms or ambient water. Our third objective was to assess if short-term glyphosate exposure affected the photochemical efficiency of the algal component of wetland biofilms, based on measurements of variable chlorophyll $a$ fluorescence during the exposure period, as this could indicate cellular stress leading to metabolic changes of these autotrophs over extended exposures.

\section{Methods}

\subsection{Biofilm colonization set-up}

All biofilms were colonized in situ on artificial substrates comprising acrylic plates measuring $44.5 \times 20.2 \times 0.6 \mathrm{~cm}$. These artificial substrates were installed as arrays, each consisting of 4 or 5 plates suspended vertically in the water column from marine buoys to hang ca. $10 \mathrm{~cm}$ below the surface of the water (Supplementary Materials Figure S1). Arrays were installed in areas of open water within the study marsh (Figure 1) at sites with $50-100 \mathrm{~cm}$ of standing water. These sites were selected to reduce shading from emergent or overhanging terrestrial vegetation and to avoid disturbance from boat traffic.

\subsection{Field-exposed biofilm installation and collection}

Arrays were deployed in areas of open water within coastal marsh habitat in Rondeau Provincial Park (2016) and Long Point Provincial Park (2017, 2018) (Figure 1) as part of a large-scale environmental monitoring program designed around the application of glyphosate-based herbicide (Roundup Custom® for Aquatic and Terrestrial Use Liquid Herbicide, registration \#32356), containing glyphosate as an isopropylamine salt with an alcohol ethoxylate surfactant (Aquasurf®, registration \#32152) to control the invasive wetland grass Phragmites australis.

The direct application of glyphosate to $P$. australis in standing water was permitted under an 
Beecraft and Rooney. 2020. Bioconcentration of glyphosate in wetland biofilms. PREPRINT. Contact rrooney@uwaterloo.ca

127 Emergency Use Registration from Health Canada’s Pest Management Regulatory Authority and

128 a Permit to Perform an Aquatic Extermination from Ontario's Ministry of Environment

129 Conservation and Parks.

Artificial substrates were given a minimum of four weeks for in situ biofilm colonization prior to the date of first collection. Plates were collected from the arrays at each site on three

132 different dates: prior to glyphosate application, $24 \mathrm{~h}$ after application, and approximately 40 days 133 after application. Plates were removed from the arrays, stored in zipper-seal bags and transported

134 in coolers back to the lab. There, we harvested the biofilm by scraping with clean cell scrapers

135 from the plate into a Whirlpak bag and rinsing any residual biomass with small amounts of 136 distilled/de-ionized water. All implements (scraper and funnel) were thoroughly rinsed with 137 deionized water between samples. Due to the high level of spatial heterogeneity of the biofilms 138 and the biomass requirements for analysis, samples from replicate plates were composited to 139 generate a single sample per array from each sampling date and site. Samples were stored frozen and then freeze dried prior to analysis for glyphosate and AMPA by the Agriculture and Food

141 Lab (AFL) at the University of Guelph, using the method described in 'Chemical analyses,'

142 below.

At the time of plate collection in the field, we collected a depth-integrated water sample

144 from each site using a plexiglass tube transferred to a polyethylene sample bottle, both triple-

145 rinsed with site water. Samples were stored on ice during transport, and then frozen until

146 delivery to AFL for analysis of glyphosate and AMPA. 
bioRxiv preprint doi: https://doi.org/10.1101/2020.08.03.234856; this version posted August 4, 2020. The copyright holder for this preprint (which was not certified by peer review) is the author/funder, who has granted bioRxiv a license to display the preprint in perpetuity. It is made available under aCC-BY-NC-ND 4.0 International license.

Beecraft and Rooney. 2020. Bioconcentration of glyphosate in wetland biofilms. PREPRINT. Contact rrooney@uwaterloo.ca

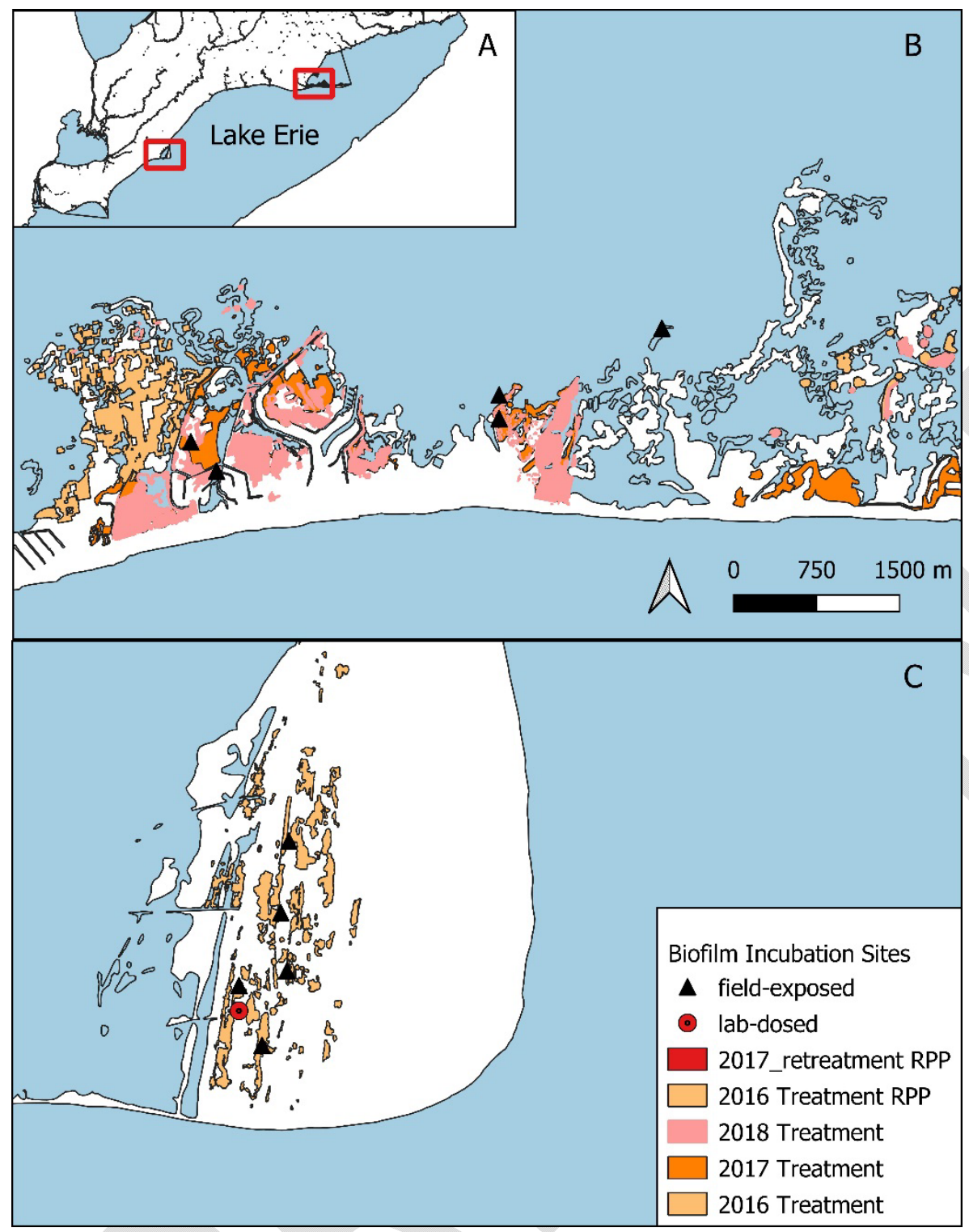

149 Figure 1. Installation sites of biofilm sampling arrays in A) two Lake Erie coastal marshes: B) Long Point

150 Provincial Park (LPP) and C) Rondeau Provincial Park (RPP), Ontario Canada. At field-exposed sites

151 (black triangles), biofilms colonized on artificial substrates were exposed to glyphosate applied to areas of

152 the wetland, indicated by colour-shaded regions corresponding to treatment areas in respective years. At

153 the 'lab-dosed' site (red circle, panel C), biofilms colonized on artificial substrates were collected and

154 transported back to the lab for controlled exposures to glyphosate in microcosms. 
Beecraft and Rooney. 2020. Bioconcentration of glyphosate in wetland biofilms. PREPRINT. Contact rrooney@uwaterloo.ca

This map was created using QGIS and shape files from Government of Canada, Statistics Canada, 2016 Census, in the EPSG:3347, NAD83 / Statistics Canada Lambert Projection.

\subsection{Laboratory-Dosed biofilms}

\subsubsection{Biofilm collection}

We installed arrays containing 15 plates for the laboratory experiments in May 2018 in an open water coastal marsh site in Rondeau Provincial Park, Ontario (Figure 1C). We selected the incubation location based on 2017 surveys, where we found no detectable levels of glyphosate residue in the water or sediment. We retrieved the plates in July and transported them to the culturing facility at the University of Waterloo in coolers, placed in high-density polyethylene (HDPE) racks such that they remained upright and immersed in $100 \mu \mathrm{m}$-filtered lake water.

\subsubsection{Laboratory set up}

We maintained the field-colonized biofilms in laboratory microcosms under controlled conditions. Microcosms comprised glass aquaria (ca. $37 \mathrm{~L}$ volume) lined with polyethylene bags to ensure glyphosate was not lost via adsorption to the glass (personal comm. from AFL to R. Rooney). Eight aquaria were filled with $100 \mu \mathrm{m}$ filtered lake water to a volume of $28 \mathrm{~L}$. The artificial substrates were held vertically (the same orientation as in situ colonization) in the HDPE racks. The colonized plates were distributed randomly among 5 microcosms, such that each microcosm contained 3 plates. The remaining 3 microcosms contained filtered lake water and 3 clean, un-colonized, plates each, which we used as experimental controls to account for glyphosate loss and/or metabolism occurring in the filtered lake water itself, and possible adsorption of glyphosate to the acrylic plates. We left the microcosms for $72 \mathrm{~h}$ to equilibrate to laboratory growth conditions: $40 \mu \mathrm{mol}$ photons $\cdot \mathrm{m}^{2} \cdot \mathrm{s}^{-1}$ at water surface from cool white fluorescent lights under a 16:8 hr light: dark cycle and constant aeration from air pumps and 
Beecraft and Rooney. 2020. Bioconcentration of glyphosate in wetland biofilms. PREPRINT. Contact rrooney@uwaterloo.ca

178

179

180

181

182

diffuser tubes (Supplementary Materials Figure S2). Temperature and dissolved oxygen were

maintained at $21 \pm 1{ }^{\circ} \mathrm{C}$ and $8.7 \pm 0.1 \mathrm{mg} \cdot \mathrm{L}^{-1}$ (ca. 100\%), respectively, though dissolved oxygen briefly reached $70-80 \%$ saturation in the coolers during transport to the culturing facility. Water level was maintained at $28 \mathrm{~L}$ with additions of filtered lake water to replaces losses from evaporation.

\subsubsection{Glyphosate exposure}

The microcosms were exposed to different concentrations of glyphosate for $24 \mathrm{~h}$ in a regression design. Treatments for microcosms containing colonized plates ('colonized microcosms') had nominal glyphosate concentrations of $0,0.01,0.1,1.0$ and $10 \mathrm{mg}$ glyphosate a.e. $\mathrm{L}^{-1}$, respectively, and $0,0.1$ and $10 \mathrm{mg}$ glyphosate a.e. $\cdot \mathrm{L}^{-1}$ for the microcosms containing clean plates ('control microcosms'). These exposure levels were chosen to encompass concentrations observed in natural surface waters by other researchers (Annett et al., 2014;

Battaglin et al., 2014) and to create a gradient from which to assess glyphosate bioconcentration.

To achieve the desired exposure levels, we added glyphosate from a stock solution (480 mg glyphosate a.e. $\mathrm{L}^{-1}$ ) made from a dilution of RoundUp Custom® (original concentration of 480 g glyphosate a.e. $\left.\cdot \mathrm{L}^{-1}\right)$.

After $24 \mathrm{~h}$, we collected water samples from each microcosm to compare measured and nominal concentrations. Samples were taken in acid washed polyethylene sample bottles, rinsed in triplicate with sample water. We harvested the biofilms from the plates using scraping tools (plastic putty knives), rinsed thoroughly with de-ionized water between samples. Biofilms from the three plates in each tank were composited, transferred to Whirlpak bags and frozen. Samples were freeze-dried at $-50^{\circ} \mathrm{C}$. Water and biofilm samples were stored frozen until delivery to AFL for analysis of glyphosate and AMPA. 
Beecraft and Rooney. 2020. Bioconcentration of glyphosate in wetland biofilms. PREPRINT. Contact rrooney@uwaterloo.ca quantum yield of photochemistry $\left(\Delta \mathrm{F} / \mathrm{F}_{\mathrm{m}}\right)$ of the photosynthetic organisms within the biofilms, red light (655 nm LED), followed by a saturating pulse of red light, which oxidizes all reaction centers and induces maximum fluorescence $\left(\mathrm{F}_{\mathrm{m}}{ }^{\prime}\right)$ (Hiriart-Baer et al., 2008; Walz GmbH, 1998).

We measured both background and maximum fluorescence in the light-adapted state, as it was not possible to dark-adapt the biofilms on the plates while taking replicate measurements and without removal from their respective treatment microcosms. $\Delta \mathrm{F} / \mathrm{F}_{\mathrm{m}}{ }^{\prime}$ is calculated as $\left(\mathrm{F}_{\mathrm{m}}{ }^{\prime}-\mathrm{F}\right) /$ $\mathrm{F}_{\mathrm{m}}$ (Cosgrove and Borowitzka, 2010). A magnetic sample holder was attached to the fiber-optic sensor to ensure the sensor remained a constant distance from the sample during measurement.

214 each treatment, starting with pre-exposure (time 0 ) and then $0.5,1,2,3,6$ and $24 \mathrm{~h}$ post-dose, 215 rinsing the sensor thoroughly between microcosms.

\subsection{Chemical Analyses}

The Agriculture and Food Laboratory (AFL) at the University of Guelph conducted the

218 analyses of glyphosate and AMPA for all water and biofilm samples (limits of detection,

219 Supplementary Materials Table S1). Samples were first homogenized, fortified with internal

220 standard and then centrifuged. The supernatant was then acidified prior to liquid chromatography

221 and mass spectrometry, and the samples quantified using a ratio of external to internal standard.

222 Results are reported in $\mathrm{ppm}$, equivalent to $\mathrm{mg} \cdot \mathrm{L}^{-1}$. 
Beecraft and Rooney. 2020. Bioconcentration of glyphosate in wetland biofilms. PREPRINT. Contact rrooney@uwaterloo.ca

\subsection{Statistical Analyses}

Linear regression analyses were used to determine how AMPA concentration in biofilm

tissues or water depends on the glyphosate concentration in that same substrate. The adsorption

processes may be occurring in the glyphosate-biofilm interaction; glyphosate is adsorbing to the

solute adsorbed to a surface and solute in the surrounding liquid, which can be expressed as:

$$
C_{s}=K C_{e}^{1 / n}
$$

Where $C_{s}$ is the concentration of adsorbed herbicide, $C_{e}$ is the herbicide concentration in the

237 using the latter and assuming that equilibrium concentrations of glyphosate in the microcosms

238 had been reached at $24 \mathrm{~h}$, supported by previous studies of pesticide accumulation in biofilms

239 (Chaumet et al., 2019; Lundqvist et al., 2012).

240 The Michaelis-Menten equation models enzyme kinetics by relating enzyme reaction rates to

241 substrate concentration, and is expressed as:

$$
v=\frac{d[P]}{d t}=\frac{V_{\max }[S]}{K_{m}+[S]}
$$


Beecraft and Rooney. 2020. Bioconcentration of glyphosate in wetland biofilms. PREPRINT. Contact rrooney@uwaterloo.ca

243 Where $v$ is reaction rate, $S$ is the substrate (glyphosate is water), $P$ is the product (glyphosate

244 adsorbed in biofilm), $V_{\max }$ is the maximum reaction rate achieved by the system, and $K_{m}$ is the

245 Michaelis constant - the substrate concentration at which the reaction rate reaches half of

246 maximum.

Bioconcentration is the retention of a substance in an organism's tissues relative to the surrounding environment, taken up by contact and respiration (Alexander, 1999; Arnot et al., 2006). Bioconcentration factor (BCF) was calculated on a dry-weight basis by dividing the concentration of glyphosate (or AMPA) in the biofilm (dry-weight) by that in the surrounding water, assuming a steady state had been reached after $24 \mathrm{~h}$ of exposure. For field sites where glyphosate and/or AMPA was detected in biofilm but not in the water, we used the limit of detection (or quantification) (Supplementary Materials Table S1), as appropriate, for the water concentration, providing a conservative estimate of the BCF. The dependence of BCF on ambient water concentrations fit a power function relationship, which we quantified using linear regression on the log-transformed values. A general linear model of the log-transformed values was used to assess if the relationship was significantly different based on application type (i.e.

258 field-exposed vs. lab-dosed) or chemical (glyphosate vs. AMPA) (Supplementary Materials 259 Table S2). In both cases the factors did not have a significant main or interaction effect and a 260 single regression was used to model the relationship. that same substrate by linear regression. Slope was estimated with an intercept estimate and with the intercept set to zero. We reported regression parameters for the latter for three reasons: analysis of variance (ANOVA) indicated no significant difference between the linear regression models with and without intercept estimates; models with an intercept predicted negative AMPA 
Beecraft and Rooney. 2020. Bioconcentration of glyphosate in wetland biofilms. PREPRINT. Contact rrooney@uwaterloo.ca

concentrations at low glyphosate concentrations; and an intercept of zero is the logical format

267 from a biological/chemical perspective. A general linear model was used to confirm that there 268 was no significant difference in the AMPA-glyphosate relationship between field-exposed and lab-dosed biofilms (Supplementary Materials Table S3) and so the regression was estimated for lab-dosed and field-exposed biofilms combined.

The effect of glyphosate exposure on the quantum yield of photochemistry, $\Delta F / F_{m}$, was

272 assessed by linear regression of the change in $\Delta \mathrm{F} / \mathrm{Fm}$ ' post-exposure, normalized to initial values

273 (i.e. (post-exposure - pre-exposure) / pre-exposure). Statistical analyses were performed in Excel

274 and R Statistical Software version 4.0.1 (R Core Team, 2020), including the packages tidyverse

275 (Wickham et al., 2019), rstatix (Kassambara, 2020) and broom (Robinson and Hayes, 2020).

2763 Results

277 The uptake of glyphosate from the surrounding water into the biofilm tissues followed a power

278 function relationship, which we modelled using the Freundlich adsorption isotherm and

279 Michaelis-Menten enzyme kinetics (Figure 2). Glyphosate and AMPA bioconcentrated in

280 biofilm tissue by two to three orders of magnitude relative to the surrounding water, with $\mathrm{BCF}_{\mathrm{DW}}$

281 ranging from 11 to 23,500 for glyphosate and from 4 to 3200 for AMPA ( 
Beecraft and Rooney. 2020. Bioconcentration of glyphosate in wetland biofilms. PREPRINT. Contact rrooney@uwaterloo.ca

282 Table 1). The $\mathrm{BCF}_{\mathrm{DW}}$ of glyphosate and AMPA were strongly dependent on the herbicide

283 concentration in the ambient water, following a negative power function relationship $\left(\mathrm{F}_{1,20}=\right.$

284 39.62, $\mathrm{p}<0.0001$ ) (Figure 3). This relationship was not significantly different between lab-dosed

285 and field-exposed biofilm samples, based on a two-factor general linear model $(\mathrm{p}=0.903$,

286 Supplementary Materials Table S2).

The concentration of AMPA was strongly and significantly dependent on the 
Beecraft and Rooney. 2020. Bioconcentration of glyphosate in wetland biofilms. PREPRINT. Contact rrooney@uwaterloo.ca significantly different between lab-dosed and field-exposed biofilms, based on a two-factor general linear model $(\mathrm{p}=0.705$, Supplementary Materials Table S3).

Algal abundance and composition were heterogeneous within the biofilms, based on the 294 variability in replicate $\Delta \mathrm{F} / \mathrm{F}_{\mathrm{m}}$ ' measurements taken from each plate and across plates within a 295 given microcosm (Supplementary Materials Table $\mathrm{S} 4$ ), though pre-exposure $\Delta \mathrm{F} / \mathrm{F}_{\mathrm{m}}$ ' was not 296 significantly different between microcosms based on one-way ANOVA $\left(\mathrm{F}_{4,166}=2.307, \mathrm{p}=\right.$ 297 0.060). There was a non-significant linear relationship between the normalized change in post298 exposure $\Delta \mathrm{F} / \mathrm{F}_{\mathrm{m}}$ ' compared to glyphosate exposure concentration $\left(\mathrm{y}=-0.0068 x+0.0755, \mathrm{~F}_{1,3}=\right.$ 299 2.628, $\mathrm{p}=0.2034$, adjusted $\mathrm{r}^{2}=0.2893$; Supplementary Materials Figure S3), suggesting acute $300(24 \mathrm{~h})$ exposure at the concentrations tested causes little to no decrease in the efficiency of 301 photochemistry (Photosystem II activity) of the algal/photosynthetic component of the biofilms. 
bioRxiv preprint doi: https://doi org/10.1101/2020.08.03.234856; this version posted Auqust 4, 2020. The copyright holder for this preprint (which was not certified by peer review) is the author/funder, who has granted bioRxiv a license to display the preprint in perpetuity. It is made available under aCC-BY-NC-ND 4.0 International license.

Beecraft and Rooney. 2020. Bioconcentration of glyphosate in wetland biofilms. PREPRINT. Contact rrooney@uwaterloo.ca

Table 1. Dry-weight bioconcentration factors $\left(\mathrm{BCF}_{\mathrm{DW}}\right)$ of glyphosate and aminomethyl

304 phosphonic acid (AMPA) in biofilms relative to the surrounding water from field-exposed and lab-dosed ('lab') biofilms. BDL and BQL indicate herbicide concentrations below methodological detection or quantification limit, respectively. In these cases, the limit of detection or quantification (LOD/LOQ) in water (Table S1) was used to conservatively estimate the $\mathrm{BCF}$, however these samples were not included in calculation of the average BCFs.

\begin{tabular}{|c|c|c|c|c|c|c|c|c|c|}
\hline \multirow{2}{*}{$\begin{array}{c}\text { Wetland } \\
\text { Site }\end{array}$} & \multirow{2}{*}{$\begin{array}{l}\text { Glyphosate } \\
\text { Treatment }\end{array}$} & \multicolumn{2}{|c|}{ Water } & \multicolumn{2}{|c|}{ Periphyton } & \multicolumn{2}{|c|}{$\mathrm{BCF}$} & \multicolumn{2}{|c|}{ Average BCF $( \pm \mathrm{SD})$} \\
\hline & & $\begin{array}{c}\text { Glyphosate } \\
\text { (ppm) }\end{array}$ & $\begin{array}{l}\text { AMPA } \\
\text { (ppm) }\end{array}$ & $\begin{array}{l}\text { Glyphosate } \\
\text { (ppm dw) }\end{array}$ & $\begin{array}{c}\text { AMPA } \\
\text { (ppm dw) }\end{array}$ & Glyphosate & AMPA & Glyphosate & AMPA \\
\hline RPP - 2016 & field-exposed & 0.068 & 0.016 & 46.0 & 26.0 & 676 & 1625 & & \\
\hline RPP - 2016 & field-exposed & 0.130 & 0.010 & 52.0 & 15.0 & 400 & 1500 & & \\
\hline RPP - 2016 & field-exposed & 0.013 & BDL & 25.0 & 3.2 & 100 & 3200 & & \\
\hline RPP - 2016 & field-exposed & 0.094 & 0.011 & 57.0 & 15.0 & 606 & 1364 & & \\
\hline RPP - 2016 & field-exposed & 0.082 & BQL & 70.0 & 14.0 & 854 & 1750 & & \\
\hline LPP - 2017 & field-exposed & 0.019 & $\mathrm{BDL}$ & 25.0 & 3.5 & 1291 & 1750 & & \\
\hline LPP - 2017 & field-exposed & BDL & $\mathrm{DL}$ & 0.5 & BDL & 460 & 4 & & \\
\hline LPP - 2017 & field-exposed & BDL & BDL & 0.3 & BDL & 290 & 4 & $835 \pm 519$ & \\
\hline LPP - 2017 & field-exposed & BDL & BDL & 23.5 & 3.1 & 23500 & 1550 & $(\mathrm{n}=11)$ & \\
\hline LPP - 2018 & field-exposed & 0.0035 & BDL & 3.4 & 0.4 & 971 & 210 & & \\
\hline LPP - 2018 & field-exposed & 0.016 & $\mathrm{BDL}$ & 6.9 & 0.3 & 431 & 125 & & \\
\hline LPP - 2018 & field-exposed & BDL & BDL & 2.5 & 0.5 & 2500 & 230 & & \\
\hline LPP - 2018 & field-exposed & 0.03 & $\mathrm{BDL}$ & 9.0 & 1.5 & 300 & 750 & & \\
\hline LPP - 2018 & field-exposed & 0.0098 & BDL & 3.3 & 0.5 & 337 & 265 & & \\
\hline LPP - 2018 & field-exposed & BDL & BDL & 2.0 & 0.5 & 2000 & 225 & & \\
\hline LPP - 2018 & field-exposed & 0.0045 & BDL & 6.3 & 1.4 & 1400 & 700 & & \\
\hline RPP - 2018 & lab $(0.01 \mathrm{ppm})$ & 0.008 & 0.001 & 4.6 & 0.4 & 613 & 175 & & \\
\hline RPP - 2018 & lab (0.1 ppm) & 0.074 & 0.008 & 10.0 & 1.1 & 135 & 147 & $199 \pm 281$ & $134 \pm 13$ \\
\hline RPP - 2018 & $\operatorname{lab}(1.0 \mathrm{ppm})$ & 0.900 & 0.068 & 34.0 & 9.2 & 38 & 135 & $(n=4)$ & $(n=3)$ \\
\hline RPP - 2018 & lab (10 ppm) & 11.000 & 0.340 & 120.0 & 41.0 & 11 & 121 & & \\
\hline
\end{tabular}
conservative estimate of average $\mathrm{BCF}$. 
Beecraft and Rooney. 2020. Bioconcentration of glyphosate in wetland biofilms. PREPRINT. Contact rrooney@uwaterloo.ca

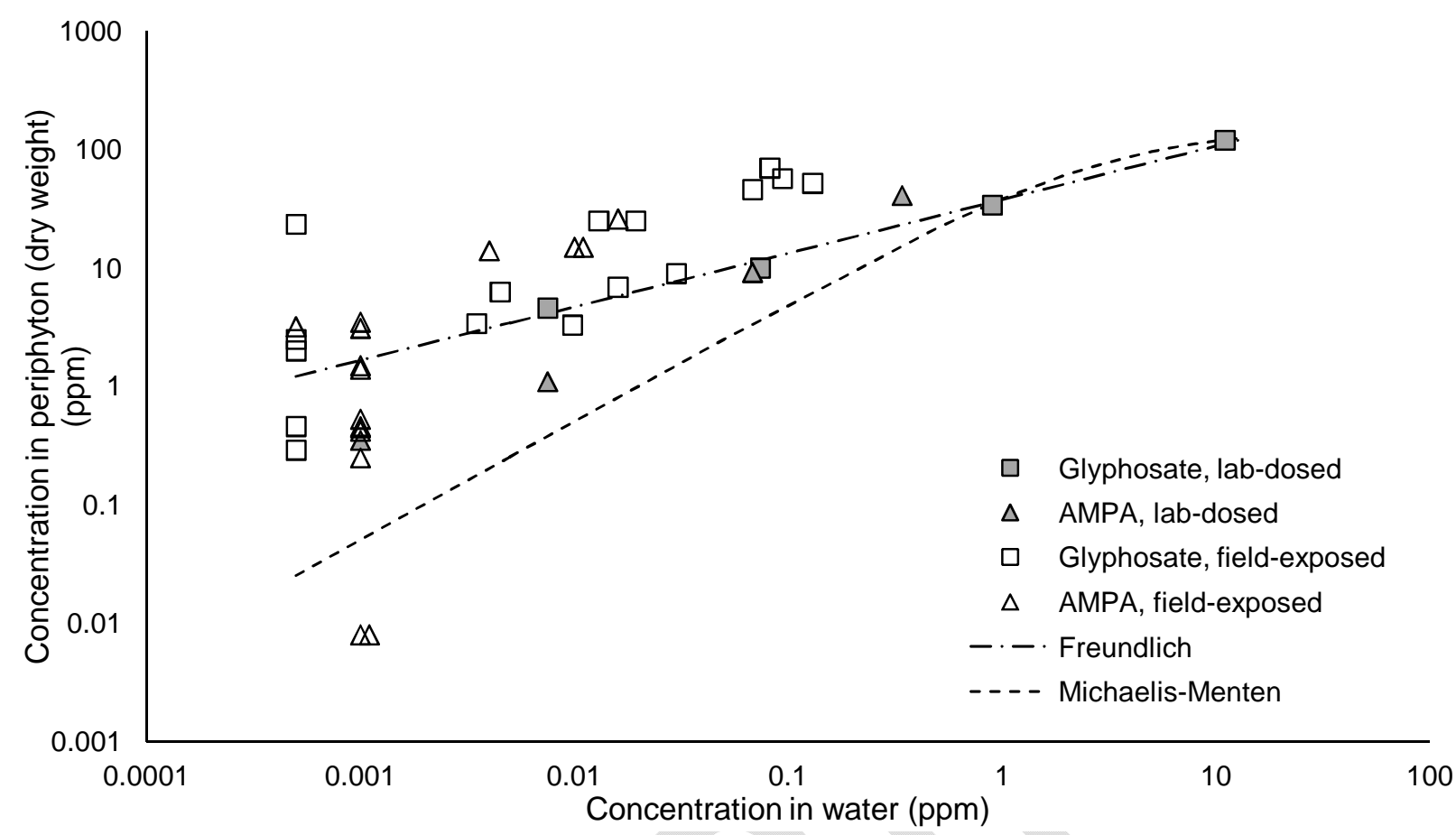

313 Figure 2. Glyphosate and AMPA retention in biofilms relative to concentrations in the

314 surrounding water. Models of glyphosate retention kinetics in biofilm tissues were estimated

315 from lab-dosed biofilms in microcosm experiments (grey symbols). We used the Freundlich

316 adsorption isotherm: $C_{s}=37.497 C_{e}{ }^{1 / 2.21}$ (dashed line) and Michaelis-Menten enzyme kinetics

$317(d[P]) / d t=(156.056[S]) /(3.039+[S])($ dotted line $)$. 
Beecraft and Rooney. 2020. Bioconcentration of glyphosate in wetland biofilms. PREPRINT. Contact rrooney@uwaterloo.ca

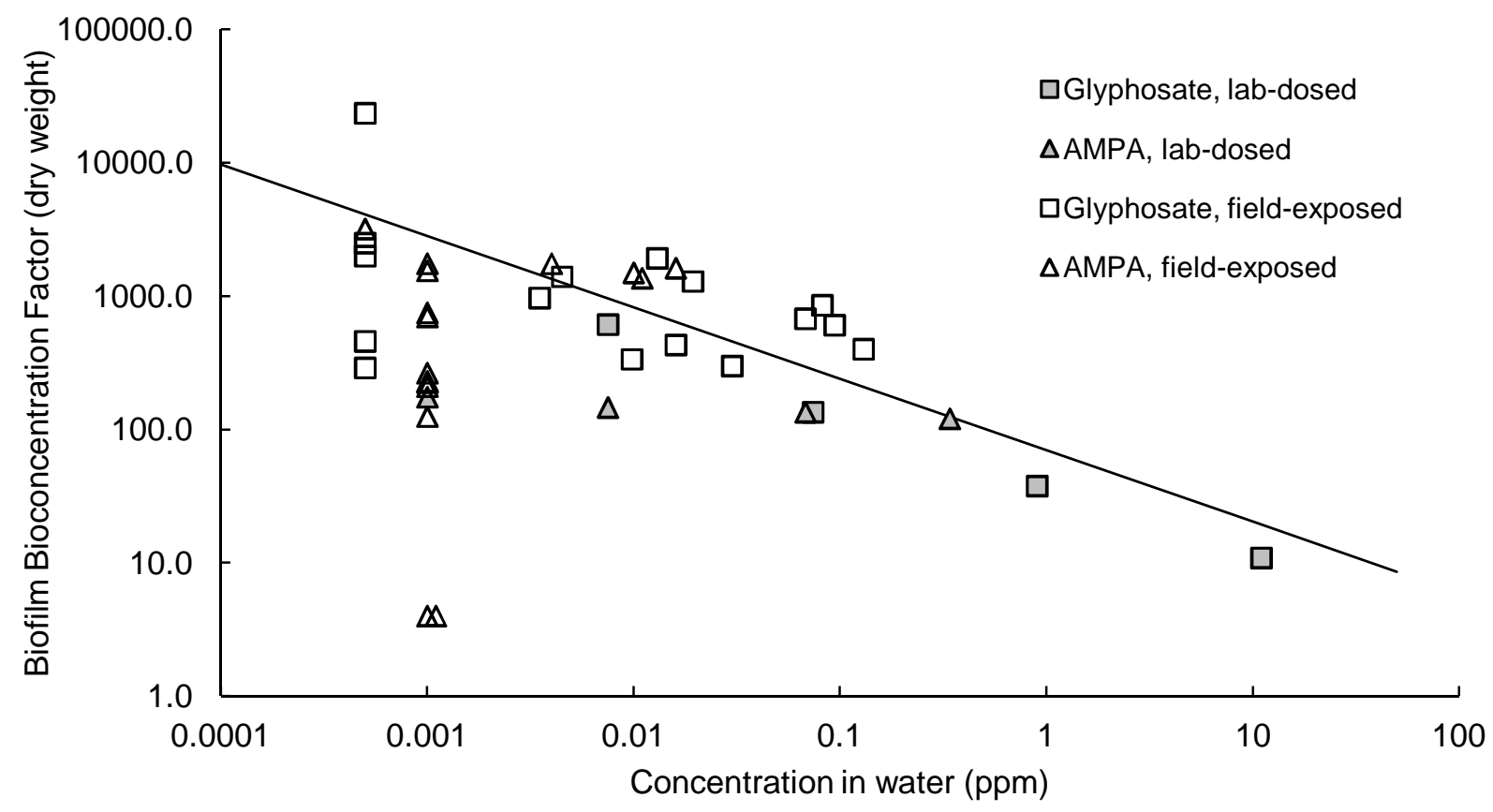

321 Figure 3. Dry-weight bioconcentration factors $\left(\mathrm{BCF}_{\mathrm{DW}}\right)$ of glyphosate and AMPA in biofilm

322 tissues from microcosms (lab-dosed) and field-exposed samples vary with ambient water

323 concentration in a power function relationship: $y=69.88 \cdot x^{-0.536}$, residual standard error $=$

$3240.3564, \mathrm{~F}_{1,20}=39.62, \mathrm{p}<0.0001$. 
Beecraft and Rooney. 2020. Bioconcentration of glyphosate in wetland biofilms. PREPRINT. Contact rrooney@uwaterloo.ca

Table 2. Linear regression analysis of the AMPA-glyphosate relationship in biofilms and

microcosm water, including control microcosms containing un-colonized plates, with regression

\begin{tabular}{lcccccc}
\hline \multirow{2}{*}{ Medium } & \multicolumn{7}{c}{ Linear regression results } \\
\cline { 2 - 7 } & Slope & df & RSE & F-statistic & p-value & $\mathbf{R}^{2}$ \\
\hline Biofilm & 0.2997 & 28 & 3.4260 & 240.2 & $2.87 \mathrm{E}-15$ & 0.8919 \\
Water (colonized microcosms) & 0.0312 & 4 & 0.0202 & 291 & $6.93 \mathrm{E}-05$ & 0.9831 \\
Water (control microcosms) & 0.0092 & 2 & 0.0036 & 941.5 & 0.00106 & 0.9968 \\
\hline parameters including degrees of freedom (df), residual standard error (RSE) and adjusted $\mathrm{R}^{2}$.
\end{tabular}
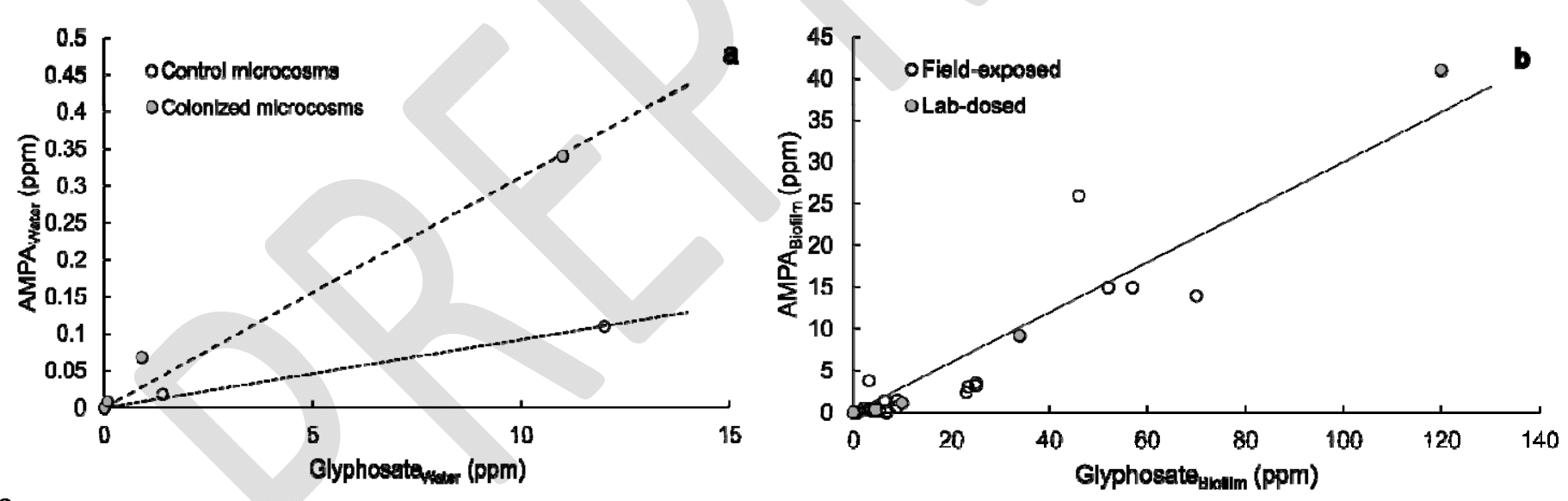

Figure 4. Concentration of the breakdown product, AMPA, increases linearly ( 
Beecraft and Rooney. 2020. Bioconcentration of glyphosate in wetland biofilms. PREPRINT. Contact rrooney@uwaterloo.ca

Table 2) with glyphosate concentration in (a) water of control (open symbols) and colonized (grey symbols) microcosms after $24 \mathrm{~h}$ exposure, and in (b) biofilm tissues dosed for $24 \mathrm{~h}$ under laboratory conditions ('lab-dosed', grey symbols) and biofilms exposed in situ for $24 \mathrm{~h}-\mathrm{ca} .40$ days ('field-exposed', open symbols).

\section{Discussion}

Biofilms are ecologically important for a number of reasons, including that they adsorb, retain and amplify solutes, accumulating substances that are otherwise highly dilute in the surrounding water (Battin et al., 2016; Sabater et al., 2002), with evidence of biofilms accumulating herbicides (Chaumet et al., 2019; Klátyik et al., 2017; Lawrence et al., 2001; Nikkila et al., 2001), insecticides (Lundqvist et al., 2012), PCBs (Wang et al., 1999), and a variety of other pesticides (Mahler et al., 2020; Rooney et al., 2020). Glyphosate is the most heavily used herbicide globally and is accumulating in our wetlands. Although its direct toxicity to fauna is well characterized as low risk (e.g. Giesy et al., 2000), there is a growing body of literature documenting the indirect effects of chronic glyphosate exposure to a wide range of aquatic organisms (Florencia Gutierrez et al., 2017; Myers et al., 2016; Pizarro et al., 2016; Vera et al., 2010). Our first objective was to determine if bioconcentration of glyphosate occurs in wetland biofilms, and test how the bioconcentration factor varies with exposure dose. Our second objective was to assess whether the glyphosate interacting with wetland biofilms is available for metabolism and to measure the extent of breakdown of glyphosate to AMPA by biofilm organisms.

We observed retention and bioconcentration of glyphosate and its breakdown product AMPA in lab-dosed and field-exposed biofilms. The herbicide had strong adsorption at low ambient concentrations, and an apparent saturation effect at higher ambient concentrations, 
Beecraft and Rooney. 2020. Bioconcentration of glyphosate in wetland biofilms. PREPRINT. Contact rrooney@uwaterloo.ca

similar to observations of diuron accumulation by Chaumet et al. (2019). This is supported by

the strong fit of both Michaelis-Menten enzyme kinetics and Freundlich adsorption models to

our data. Furthermore, observed BCFs more closely followed the Freundlich adsorption isotherm

at low ambient water concentrations $(<1 \mathrm{ppm})$ and Michaelis-Menten kinetics at higher

concentrations (> $1 \mathrm{ppm}$ ). Biologically, this may correspond to initial, rapid adsorption of

herbicide to biofilm surfaces and the extracellular polymeric substances of the biofilm matrix,

followed by slower enzymatic uptake and metabolism of the herbicide by biofilm

microorganisms. The result is a BCF inversely proportional to glyphosate concentration in the surrounding water.

exposed biofilms, likely because the observed herbicide concentrations in the water were lower

in the field compared to the laboratory-dosed microcosms. However, the relationship of BCF to

ambient water concentrations did not differ significantly between field-exposed and lab-dosed

biofilms, or between glyphosate and AMPA, suggesting that the microcosms captured the same

glyphosate and AMPA detected in natural surface waters are typically quite low (e.g., $0.159 \mu \mathrm{g}$

375 glyphosate $\cdot \mathrm{L}^{-1}$ (Glozier et al., 2012); < $0.03 \mu \mathrm{g}$ glyphosate $\cdot \mathrm{L}^{-1}$ (Annett et al., 2014; Battaglin et

376 al., 2014), 0.1-0.3 $\mu \mathrm{g}$ glyphosate $\cdot \mathrm{L}^{-1}$ (Carles et al., 2019)), the glyphosate concentration in

377 biofilm tissues may be much higher due to bioconcentration, with BCFs greater than 800 at concentrations reported to be typical of surface waters.

Our results contradict the expectation that glyphosate will not bioaccumulate or 
Beecraft and Rooney. 2020. Bioconcentration of glyphosate in wetland biofilms. PREPRINT. Contact rrooney@uwaterloo.ca

and Kilgour, 2018; Solomon and Thompson, 2003). On the other hand, bioconcentration in

biofilms offers an explanation for the apparent rapid dissipation of glyphosate from surface

waters (Goldsborough and Brown, 1993); e.g., like us, Klátyik et al. (2017) observed the

accelerated dissipation of glyphosate from river water in microcosms containing biofilms within

$24 \mathrm{~h}$ of herbicide addition. Glyphosate bioconcentration has been observed in other organisms:

(Pérez et al., 2017), and in the oligochaete Lumbriculus variegatus, with the uptake/adsorption

relative to water concentration fitting the Freundlich adsorption isotherm (Contardo-Jara et al., 2009). Glyphosate concentrations in surface water can spike immediately after application and runoff events, and then drop very rapidly, with concentrations much lower in water collected was previously realized, by retaining it within the biofilm tissues rather than in the water. It would be useful to know the rate and extent of depuration of glyphosate and AMPA from biofilms back into the surrounding water column as herbicide concentrations in the water

398 decrease, which would inform potential flushing of glyphosate from biofilms after herbicide exposure. 
Beecraft and Rooney. 2020. Bioconcentration of glyphosate in wetland biofilms. PREPRINT. Contact rrooney@uwaterloo.ca

405

406

407

408

409

410

411

412

413

414

415

416

417

418

419

420

421

422

surrounding water, consistent with observations from other studies (Carles et al., 2019; Klátyik et al., 2017). The stable structure of a biofilm allows for the formation of a functional community that is more dense and metabolically efficient compared to planktonic cells (Besemer, 2015). When comparing the dependence of AMPA concentration to glyphosate concentration in biofilm and water samples, linear regression slopes were highest for the biofilms themselves, followed by water from microcosms containing colonized plates, and lowest in water from control microcosms. This indicates that microorganisms present in both the $100 \mu \mathrm{m}$-filtered lake water and the biofilms are metabolizing glyphosate to AMPA, but that the biofilms are primarily responsible for glyphosate metabolism and are releasing AMPA into the surrounding water. The rate of conversion (slope) from glyphosate to AMPA was not significantly different between the lab-dosed and field-exposed biofilms, and was two orders of magnitude higher within the biofilms compared to filtered lake water. Thus, we conclude that biofilms increase the rate and extent of glyphosate metabolism in their environment, as suggested by Lawrence et al., (2001) and Klatyik et al. (2017). These results offer a possible explanation for the observations of Imfeld et al. (2013) that transport and degradation of glyphosate in stormwater wetlands are influenced by the vegetation: increased vegetation may have provided increased surface area for biofilm colonization, and retention and degradation of the biofilms facilitated the observed changes in water concentrations.

Glyphosate and its breakdown product AMPA are frequently detected in surface waters of Canadian streams and rivers (e.g. Struger, Stempvoort, and Brown 2015) usually at levels below the Canadian Water Quality Guideline for the protection of aquatic life $(800 \mu \mathrm{g}$ glyphosate $\mathrm{L}^{-1}$ for chronic exposure, (CCME, 2012)). However, if concentrations in biofilms are orders of magnitude higher than surface waters, it introduces a dietary exposure route to grazing 
Beecraft and Rooney. 2020. Bioconcentration of glyphosate in wetland biofilms. PREPRINT. Contact rrooney@uwaterloo.ca

428

429

430

431

432

433

434

435

436

437

438

439

440

441

442

443

444

445

446

447

448

449

450

organisms via consumption (Lundqvist et al., 2012). Despite considerable research on organism sensitivity to glyphosate-based herbicides, there is also disparity in the reported results. Toxicity responses vary with species, exposure route and duration (Annett et al., 2014), ranging from: negligible (reviewed in Breckels and Kilgour, 2018)(Breckels and Kilgour, 2018); to moderate (e.g. cladoceran (Tsui and Chu, 2003); snails (Druart et al., 2017); amphibians (Carvalho et al., 2018; Druart et al., 2017); fish (Zebral et al., 2018)); to strong negative impacts (e.g., amphibians (King and Wagner, 2010; Paganelli et al., 2010; Relyea and Jones, 2009)). This apparent discrepancy over the magnitude of risk that glyphosate poses to aquatic biota remains because the effects of glyphosate-based herbicides on non-target aquatic organisms differ by dose, exposure route, timing of exposure and taxon studied (Annett et al., 2014; Reno et al., 2014; Tsui and $\mathrm{Chu}, 2003)$. It is further complicated because the commercially available glyphosate formulations comprise a proprietary blend of constituents to improve herbicide efficacy (Druart et al., 2017; Klátyik et al., 2017; Myers et al., 2016). Some studies have attributed the toxicity of glyphosate-based herbicide formulations to these additives, rather than the glyphosate per se (e.g. Reno et al., 2014; Tsui and Chu, 2003), yet these additives may be challenging to identify and differ among products, hampering synthesis of the toxicological literature on glyphosate (reviewed in Annett, Habibi, and Hontela 2014). Thus, the formulation and concentration in acid equivalents need to be considered in studies assessing risk to aquatic life.

Bioconcentration of glyphosate in biofilm tissues may be of particular concern for microalgal/photosynthetic organisms living in biofilms and consequently exposed to potentially harmful levels of glyphosate and AMPA, exceeding CCME guidelines, even if levels in the ambient water appear safe. Microalgae in biofilms are important contributors to shallow water food webs, oxygen and energy production via photosynthesis, and biogeochemical nutrient 
Beecraft and Rooney. 2020. Bioconcentration of glyphosate in wetland biofilms. PREPRINT. Contact rrooney@uwaterloo.ca

cycling (Battin et al., 2016). Microalgae and cyanobacteria exhibit variable and species-specific

responses to glyphosate exposure (Choi et al., 2012; Forlani et al., 2008; Lozano et al., 2018;

Smedbol et al., 2017; C. Wang et al., 2016). Cyanobacteria have been found to be tolerant to

ppm) stimulating growth of some cyanobacteria (Berman et al., 2020; Drzyzga and Lipok, 2018).

464 phosphorus when exposed to glyphosate (Berman et al., 2020; Carles et al., 2019; Huntscha et nutrient source may play a role. 
Beecraft and Rooney. 2020. Bioconcentration of glyphosate in wetland biofilms. PREPRINT. Contact rrooney@uwaterloo.ca

474 observed only a weak, non-significant trend of declining $\Delta \mathrm{F} / \mathrm{F}_{\mathrm{m}}{ }^{\prime}$ with glyphosate exposure.

475 Importantly, average post-exposure $\Delta \mathrm{F} / \mathrm{F}_{\mathrm{m}}$ ' was $>0.6$ for all exposure concentrations, a quantum 476 yield value typical of healthy algal cells (Campbell et al., 1998; Kolber et al., 1988). Glyphosate

477 inhibits aromatic amino acid synthesis and does not directly target the photosynthetic apparatus.

478 Hence, when additional stressors are absent and requirements for new cellular protein are

479 minimal, it seems reasonable that brief exposures to 1-10 ppm glyphosate would have limited

480 effects on the photosynthetic efficiency of biofilms. In contrast, maximum quantum yield $\left(\mathrm{F}_{\mathrm{v}} / \mathrm{F}_{\mathrm{m}}\right)$

481 of freshwater phytoplankton was suppressed following glyphosate exposure $(<15 \mathrm{ppm}$ (Choi et

482 al., 2012); 0.5 - 1 ppm (Smedbol et al., 2017)), with responses following Michaelis-Menten

483 saturation kinetics (Choi et al., 2012), but also showing considerable species-specific differences

484 in sensitivity (Smedbol et al., 2017). Quantum yield alone may not be sensitive enough to assess

485 herbicide stress in periphyton communities over short time scales (Dorigo and Leboulanger,

486 2001; Tiam et al., 2015), in particular for herbicides that do not directly affect Photosystem II

487 (Feckler et al., 2018). Our results support this assessment, and we recommend parallel

measurement of different responses over time to effectively capture herbicide effects on algal

489 physiology and metabolism.

The range of response factors and species-specific variability suggests changes in

491 photosynthetic community structure are likely following glyphosate exposure (Berman et al.,

492 2020; Huntscha et al., 2018; Klátyik et al., 2017; Lozano et al., 2018; Pizarro et al., 2016;

493 Smedbol et al., 2018). Changes to algal community composition have been observed at

494 environmentally relevant concentrations of glyphosate (Magbanua et al., 2013), including

495 increased abundance of chlorophytes (Klátyik et al., 2017) and cyanobacteria (Berman et al.,

496 2020; Huntscha et al., 2018; Lozano et al., 2018; Pérez et al., 2007). We expect that chronic 
Beecraft and Rooney. 2020. Bioconcentration of glyphosate in wetland biofilms. PREPRINT. Contact rrooney@uwaterloo.ca

exposure to glyphosate may favour taxa with resistant forms of the target enzyme EPSPS or

other tolerance mechanisms (Forlani et al., 2008; Huntscha et al., 2018), as well as those best able to utilize metabolically released phosphorus (Berman et al., 2020; Forlani et al., 2008; C.

Wang et al., 2016). If changes in community composition negatively influence the health or

abundance of species that are preferentially grazed by other organisms, indirect trophic effects

water quality and macrophyte abundance (Berman et al., 2020; Pizarro et al., 2016). This points

to the need for future work examining the effects of chronic exposure on community structure

\subsection{Conclusions}

The results presented reveal the ability of biofilms to metabolize glyphosate and retain

512 and bioconcentrate glyphosate and its breakdown product AMPA. This demonstrates the

513 importance of biofilms to improving water quality, facilitating contaminant removal from surface

514 water and runoff - a valuable ecosystem function provided by wetlands and facilitated by

515 biofilms. This is a potential explanation for the observed rapid dissipation of glyphosate from

516 surface waters and the low levels detected even a short time after runoff events (Goldsborough

517 and Beck, 1989; Goldsborough and Brown, 1993; Imfeld et al., 2013; Peruzzo et al., 2008).

518 However, these same features present a potential negative impact, as biofilms also provide

519 habitat and a food source for many invertebrates and juvenile aquatic organisms, including fish 
Beecraft and Rooney. 2020. Bioconcentration of glyphosate in wetland biofilms. PREPRINT. Contact rrooney@uwaterloo.ca

and amphibians (Battin et al., 2016). Bioconcentration of glyphosate and other pesticides in

biofilms presents a contaminant delivery route to higher trophic levels that is not well understood

522 (Lundqvist et al., 2012). The majority of ecotoxicological risk assessments examine

523 physiological effects resulting from immersion, and we may be under-recognizing the potential

524 ecological risk of contaminants, like glyphosate, that are bioconcentrating in biofilms and

525 subsequently being consumed. Risk assessments for contaminants need to consider both the

526 toxicity as well as the different exposure routes to organisms, and future ecotoxicity research

527 should incorporate the effects of acute and chronic dietary exposure of glyphosate, as well as

528 other contaminants, to aquatic biota.

\section{Acknowledgements}

531 Funding: This work was funded by research agreement NCA_20180507152929575 from the Ontario

532 Ministry of Natural Resources and Forestry, National Science and Engineering Research Council of

533 Canada Discovery Grant RGPIN-03846, and the Mitacs Career Connect program.

534 Field and laboratory assistance was provided by G. Howell, D. Anderson, H. Polowyk, S. Yuckin, H.

535 Quinn-Austin, J. Pearson, L. Koiter, M. Tanguay and C. Robichaud. We thank _- anonymous reviewers

536 for their feedback that improved this manuscript.

5376 References

538 (WHO), W.H.O., 2005. Glyphosate and AMPA in Drinking-Water.

539 Alexander, D.E., 1999. Bioaccumulation, bioconcentration, biomagnification, in: Environmental

540 Geology. Springer Netherlands, Dordrecht, pp. 43-44. https://doi.org/10.1007/1-4020-4494-1_31

541 Alister, C.A., Araya, M.A., Kogan, M., 2010. Adsorption and desorption variability of four herbicides 
Beecraft and Rooney. 2020. Bioconcentration of glyphosate in wetland biofilms. PREPRINT. Contact rrooney@uwaterloo.ca https://doi.org/10.1080/03601234.2011.534372

Amrhein, N., Deus, B., Gehrke, P., Steinrucken, H.C., 1980. The Site of the Inhibition of the Shikimate Pathway by Glyphosate. II. Interference of Glypyhosate with Chorismate formation in vivo and in vitro. Plant Physiol 66, 830-834.

Annett, R., Habibi, H.R., Hontela, A., 2014. Impact of glyphosate and glyphosate-based herbicides on the freshwater environment. J. Appl. Toxicol. 34, 458-479. https://doi.org/10.1002/jat.2997

Arnot, J.A., APC Gobas, F., Gobas, F., 2006. A review of bioconcentration factor (BCF) and bioaccumulation factor (BAF) assessments for organic chemicals in aquatic organisms. Environ. Rev 14, 257-297. https://doi.org/10.1139/A06-005

Battaglin, W.A., Meyer, M.T., Kuivila, K.M., Dietze, J.E., 2014. Glyphosate and its degradation product AMPA occur frequently and widely in U.S. soils, surface water, groundwater, and precipitation. J. Am. Water Resour. Assoc. 50, 275-290. https://doi.org/10.1111/jawr.12159

Battin, T.J., Besemer, K., Bengtsson, M.M., Romani, A.M., Packmann, A.I., 2016. The ecology and biogeochemistry of stream biofilms. Nat Rev Microbiol 14, 251-263. https://doi.org/10.1038/nrmicro.2016.15

Benbrook, C.M., 2016. Trends in glyphosate herbicide use in the United States and globally. Environ. Sci. Eur. 28, 3. https://doi.org/10.1186/s12302-016-0070-0

Berman, M.C., Llames, M.E., Minotti, P., Fermani, P., Quiroga, M. V., Ferraro, M.A., Metz, S., Zagarese, H.E., 2020. Field evidence supports former experimental claims on the stimulatory effect of glyphosate on picocyanobacteria communities. Sci. Total Environ. 701, 134601. https://doi.org/10.1016/j.scitotenv.2019.134601

Besemer, K., 2015. Biodiversity, community structure and function of biofilms in stream ecosystems. 
Beecraft and Rooney. 2020. Bioconcentration of glyphosate in wetland biofilms. PREPRINT. Contact rrooney@uwaterloo.ca

Bonnineau, C., Sague, I.G., Urrea, G., Guasch, H., 2012. Light history modulates antioxidant and photosynthetic responses of biofilms to both natural (light) and chemical (herbicides) stressors. Ecotoxicology 21, 1208-1224. https://doi.org/10.1007/s 10646-012-0876-5

Breckels, R., Kilgour, B., 2018. Aquatic herbicide applications for the control of aquatic plants in Canada: effects to nontarget aquatic organisms. Environ. Rev. 26, 333-338. https://doi.org/10.1139/er-2018-

Campbell, D., Hurry, V., Clarke, A.K., Gustafsson, P., Öquist, G., 1998. Chlorophyll Fluorescence Analysis of Cyanobacterial Photosynthesis and Acclimation. Microbiol. Mol. Biol. Rev. 62, 667683. https://doi.org/10.1128/mmbr.62.3.667-683.1998

Carles, L., Gardon, H., Joseph, L., Sanchís, J., Farré, M., Artigas, J., 2019. Meta-analysis of glyphosate contamination in surface waters and dissipation by biofilms. Environ. Int. 124, 284-293.

Carvalho, W.F., Franco, F.C., Godoy, F.R., Folador, D., Avelar, J.B., Nomura, F., da Cruz, A.D., de Sabóia-Morais, S.M.T., Bastos, R.P., e Silva, D. de M., 2018. Evaluation of Genotoxic and Mutagenic Effects of Glyphosate Roundup Original ${ }^{\circledR}$ in Dendropsophus minutus Peters, 1872 Tadpoles. South Am. J. Herpetol. 13, 220-229. https://doi.org/10.2994/SAJH-D-17-00016.1 the protection of aquatic life: glyphosate, in: Canadian Environmental Quality Guidelines. CCME, Winnipeg, Canada. 
Beecraft and Rooney. 2020. Bioconcentration of glyphosate in wetland biofilms. PREPRINT. Contact rrooney@uwaterloo.ca

588

589

590

591

592

593

594

595

596

597

598

599

600

601

602

603

604

605

606

607

608

609

610

Choi, C.J., Berges, J.A., Young, E.B., 2012. Rapid effects of diverse toxic water pollutants on chlorophyll a fluorescence: Variable responses among freshwater microalgae. Water Res. 46, 2615-2626. https://doi.org/10.1016/J.WATRES.2012.02.027

Contardo-Jara, V., Klingelmann, E., Wiegand, C., 2009. Bioaccumulation of glyphosate and its formulation Roundup Ultra in Lumbriculus variegatus and its effects on biotransformation and antioxidant enzymes. Environ. Pollut. 157, 57-63. https://doi.org/10.1016/j.envpol.2008.07.027

Cosgrove, J., Borowitzka, Michael A, 2010. Chlorophyll a Fluorescence in Aquatic Sciences: Methods and Applications, in: Sugget, D.J., Prasil, O., Borowitzka, M.A. (Eds.), Chlorophyll a Fluorescence in Aquatic Sciences: Methods and Applications. Springer, New York, pp. 1-18. https://doi.org/10.1007/978-90-481-9268-7

Cui, Y., Jin, L., Ko, S.-R., Chun, S.-J., Oh, H.-S., Lee, C.S., Srivastava, A., Oh, H.-M., Ahn, C.-Y., 2017. Periphyton effects on bacterial assemblages and harmful cyanobacterial blooms in a eutrophic freshwater lake: a mesocosm study. Sci. Rep. 7, 7827. https://doi.org/10.1038/s41598-017-08083-x

Dorigo, U., Leboulanger, C., 2001. A pulse-amplitude modulated fluorescence-based method for assessing the effects of photosystem II herbicides on freshwater periphyton. J. Appl. Phycol. 13, $509-515$.

Druart, C., Gimbert, F., Scheifler, R., de Vaufleury, A., 2017. A full life-cycle bioassay with Cantareus aspersus shows reproductive effects of a glyphosate-based herbicide suggesting potential endocrine disruption. Environ. Pollut. 226, 240-249. https://doi.org/10.1016/j.envpol.2017.03.061

Drzyzga, D., Lipok, J., 2018. Glyphosate dose modulates the uptake of inorganic phosphate by freshwater cyanobacteria. J. Appl. Phycol. 30, 299-309. https://doi.org/10.1007/s10811-017-1231-2/Published

Duke, S.O., Powles, S.B., 2008. Glyphosate: a once-in-a-century herbicide. Pest Manag. Sci. 63, 11001106. https://doi.org/10.1002/ps 
Beecraft and Rooney. 2020. Bioconcentration of glyphosate in wetland biofilms. PREPRINT. Contact rrooney@uwaterloo.ca

611

612

613

614

615

616

617

618

619

620

621

622

623

624

625

626

627

628

629

630

631

632

633

634

Feckler, A., Rakovic, J., Kahlert, M., Tröger, R., Bundschuh, M., 2018. Blinded by the light: Increased chlorophyll fluorescence of herbicide-exposed periphyton masks unfavorable structural responses during exposure and recovery. Aquat. Toxicol. 203, 187-193.

https://doi.org/10.1016/j.aquatox.2018.08.015

Fernandes, G., Aparicio, V.C., Camotti Bastos, M., De Gerónimo, E., Labanowski, J., Prestes, D., Zanella, R., Rheinheimer, D., Santos, D., 2019. Indiscriminate use of glyphosate impregnates river epilithic biofilms in southern Brazil. Sci. Total Environ. 651, 1377-1387. https://doi.org/10.1016/j.scitotenv.2018.09.292

Florencia Gutierrez, M., Battauz, Y., En Caisso, B., 2017. Disruption of the hatching dynamics of zooplankton egg banks due to glyphosate application. Chemosphere 171, 644-653. https://doi.org/10.1016/j.chemosphere.2016.12.110

Forlani, G., Pavan, M., Gramek, M., Kafarski, P., Lipok, J., 2008. Biochemical Bases for a Widespread Tolerance of Cyanobacteria to the Phosphonate Herbicide Glyphosate. Plant Cell Physiol. 49, 443456. https://doi.org/10.1093/pcp/pcn021

Giesy, J., Dobson, S., Solomon, K., 2000. Ecotoxicological risk assessment for Roundup (R) Herbicide. Rev. Environ. Contam. Toxicol. 167, 35-120.

Glozier, Nancy E, Struger, John, Cessna, Allan J, Gledhill, Melissa, Rondeau, Myriam, Ernst, William R, Sekela, Mark A, Cagampan, Steve J, Sverko, Ed, Murphy, C., Murray, Janine L, Donald, David B, Glozier, N E, Struger, J, Cagampan, S J, Sverko, E, Cessna, A J, Gledhill, M, Sekela, M A, Rondeau, M, Ernst, W R, Murphy, : C, Murray, J L, Donald, D B, 2012. Occurrence of glyphosate and acidic herbicides in select urban rivers and streams in Canada, 2007. Env. Sci Pollut Res 19, 821-834. https://doi.org/10.1007/s11356-011-0600-7

Goldsborough, L.G., Beck, A.E., 1989. Rapid dissipation of glyphosate in small forest ponds. Arch. Environm. Contain. Toxicol 18, 537-544. 
Beecraft and Rooney. 2020. Bioconcentration of glyphosate in wetland biofilms. PREPRINT. Contact rrooney@uwaterloo.ca

635

636

637

638

639

640

641

642

643

644

645

646

647

648

649

650

651

652

653

654

655

656

657

Goldsborough, L.G., Brown, D.J., 1993. Phosphonate and AMPA disspation in acid water and sediments.pdf. Environ. Toxicol. Chem. 12, 1139-1147.

Goldsborough, L.G., Brown, D.J., 1988. Effect of glyphosate (Roundup® formulation) on periphytic algal photosynthesis. Bull. Environ. Contam. Toxicol. 41, 253-260. https://doi.org/10.1007/BF01705439

Hébert, M.P., Fugère, V., Gonzalez, A., 2019. The overlooked impact of rising glyphosate use on phosphorus loading in agricultural watersheds. Front. Ecol. Environ. 17, 48-56. https://doi.org/10.1002/fee.1985

Henderson, A.M., Gervais, J.A., Luukinen, B., Buhl, K., Stone, D.., 2010. Glyphosate Technical Fact Sheet.

Hiriart-Baer, V.P., Arciszewski, T.J., Malkin, S.Y., Guildford, S.J., Hecky, R.E., 2008. Use of pulseamplitude-modulated fluorescence to assess the physiological status of Cladophora sp. along a water quality gradient. J. Phycol. 44, 1604-1613. https://doi.org/10.1111/j.1529-8817.2008.00588.x

Huntscha, S., Stravs, M.A., Bu $\square$, A., Ahrens, C.H., Ju $\square$, Il, Frey, E., Pomati, F., Hollender, J., Buerge, I.J., Balmer, M.E., Poiger, T., 2018. Seasonal Dynamics of Glyphosate and AMPA in Lake Greifensee: Rapid Microbial Degradation in the Epilimnion During Summer. Environ. Sci. Technol. 52, 4641-4649. https://doi.org/10.1021/acs.est.8b00314

Ilikchyan, I.N., McKay, R.M.L., Zehr, J.P., Dyhrman, S.T., Bullerjahn, G.S., 2009. Detection and expression of the phosphonate transporter gene $\mathrm{phnD}$ in marine and freshwater picocyanobacteria. Environ. Microbiol. 11, 1314-1324. https://doi.org/10.1111/j.1462-2920.2009.01869.x

Imfeld, G., Lefrancq, M., Maillard, E., Payraudeau, S., 2013. Transport and attenuation of dissolved glyphosate and AMPA in a stormwater wetland. Chemosphere 90, 1333-1339. https://doi.org/10.1016/j.chemosphere.2012.04.054 
Beecraft and Rooney. 2020. Bioconcentration of glyphosate in wetland biofilms. PREPRINT. Contact rrooney@uwaterloo.ca

658

659

660

661

662

663

664

665

666

667

668

669

670

671

672

673

674

675

676

677

678

679

680

Iummato, M.M., Pizarro, H., Cataldo, D., Di Fiori, E., dos Santos Afonso, M., del Carmen Ríos de Molina, M., Juárez, Á.B., 2017. Effect of glyphosate acid on biochemical markers of periphyton exposed in outdoor mesocosms in the presence and absence of the mussel Limnoperna fortunei. Environ. Toxicol. Chem. 36, 1775-1784. https://doi.org/10.1002/etc.3820

Janßen, R., Skeff, W., Werner, J., Wirth, M.A., Kreikemeyer, B., Schulz-bull, D., Labrenz, M., 2019. A Glyphosate Pulse to Brackish Long-Term Microcosms Has a Greater Impact on the Microbial Diversity and Abundance of Planktonic Than of Biofilm Assemblages. Front. Mar. Sci. 6, 1-17. https://doi.org/10.3389/fmars.2019.00758

Kassambara, A., 2020. rstatix: Pipe-Friendly Framework for Basic Statistical Tests.

King, J.J., Wagner, R.S., 2010. Toxic Effects of the Herbicide Roundup ${ }^{\circledR}$ Regular on Pacific Northwestern Amphibians. Northwest. Nat. 91, 318-324. https://doi.org/10.1898/NWN09-25.1

Kish, P.A., 2006. Evaluation of Herbicide Impact on Periphyton Community Structure Using the Matlock Periphytometer. J. Freshw. Ecol. 21, 341-348. https://doi.org/10.1080/02705060.2006.9665004

Klátyik, S., Takács, E., Mörtl, M., Földi, A., Trábert, Z., Ács, É., Darvas, B., Székács, A., 2017. Dissipation of the herbicide active ingredient glyphosate in natural water samples in the presence of biofilms. Int. J. Environ. Anal. Chem. 97, 901-921. https://doi.org/10.1080/03067319.2017.1373770

Kolber, Z., Zehr, J., Falkowski, P., 1988. Effects of growth irradiance and nitrogen limitation on photosynthetic energy-conversion in photosystem-II. Plant Physiol 88, 923-929. https://doi.org/10.1104/pp.88.3.923

Lawrence, J.R., Kopf, G., Headley, J. V, Neu, T.R., 2001. Sorption and metabolism of selected herbicides in river biofilm communities. Can J Microbiol 47, 634-641. https://doi.org/10.1139/cjm-47-7-634

Liu, T., Xu, S., Lu, Shaoyong, Qin, P., Ding, H., Liu, Y., Guo, X., Liu, X., Lu, S, 2019. A review on removal of organophosphorus pesticides in constructed wetland: Performance, mechanism and 
Beecraft and Rooney. 2020. Bioconcentration of glyphosate in wetland biofilms. PREPRINT. Contact rrooney@uwaterloo.ca

681

682

683

684

685

686

687

688

689

690

691

692

693

694

695

696

697

698

699

700

701

702

703

influencing factors. Sci. Total Environ. 651, 2247-2268.

https://doi.org/10.1016/j.scitotenv.2018.10.087

Lozano, V., Vinocur, A., Sabio García, C., Allende, L., Cristos, D., Rojas, D., Wolansky, M., Pizarro, H., 2018. Effects of glyphosate and 2,4-D mixture on freshwater phytoplankton and periphyton communities: a microcosms approach. Ecotoxicol. Environ. Saf. 148, 1010-1019. https://doi.org/10.1016/j.ecoenv.2017.12.006

Lundqvist, A., Bertilsson, S., Goedkoop, W., 2012. Interactions with DOM and biofilms affect the fate and bioavailability of insecticides to invertebrate grazers. Ecotoxicology 21, 2398-2408. https://doi.org/10.1007/s10646-012-0995-z

Lupi, L., Bedmar, F., Puricelli, M., An Marino, D., Aparicio, V.C., Wunderlin, D., Miglioranza, K.S.B., 2019. Glyphosate runoff and its occurrence in rainwater and subsurface soil in the nearby area of agricultural fields in Argentina. https://doi.org/10.1016/j.chemosphere.2019.03.090

Magbanua, F.S., Townsend, C.R., Hageman, K.J., Lange, K., Lear, G., Lewis, G.D., Matthaei, C.D., 2013. Understanding the combined influence of fine sediment and glyphosate herbicide on stream periphyton communities. Water Res. 47, 5110-5120. https://doi.org/10.1016/j.watres.2013.05.046

Mahler, B.J., Schmidt, T.S., Nowell, L.H., Qi, S.L., Van Metre, P.C., Hladik, M.L., Carlisle, D.M., Munn, M.D., May, J., 2020. Biofilms Provide New Insight into Pesticide Occurrence in Streams and Links to Aquatic Ecological Communities. Environ. Sci. Technol 54, 5509-5519. https://doi.org/10.1021/acs.est.9b07430

Majewski, M.S., Coupe, R.H., Foreman, W.T., Capel, P.D., 2014. Pesticides in Mississippi air and rain: A comparison between 1995 and 2007. Environ. Toxicol. Chem. 33, 1283-1293. https://doi.org/10.1002/etc.2550

Medalie, L., Baker, N.T., Shoda, M.E., Stone, W.W., Meyer, M.T., Stets, E.G., Wilson, M., 2020. 
Beecraft and Rooney. 2020. Bioconcentration of glyphosate in wetland biofilms. PREPRINT. Contact rrooney@uwaterloo.ca

704

705

706

707

708

709

710

711

712

713

714

715

716

717

718

719

720

721

722

723

724

725

726

727

Influence of land use and region on glyphosate and aminomethylphosphonic acid in streams in the USA. Sci. Total Environ. 707, 136008. https://doi.org/10.1016/j.scitotenv.2019.136008

Montiel-León, J.M., Munoz, G., Vo Duy, S., Do, D.T., Vaudreuil, M.A., Goeury, K., Guillemette, F., Amyot, M., Sauvé, S., 2019. Widespread occurrence and spatial distribution of glyphosate, atrazine, and neonicotinoids pesticides in the St. Lawrence and tributary rivers. Environ. Pollut. 250, 29-39. https://doi.org/10.1016/j.envpol.2019.03.125

Myers, J.P., Antoniou, M.N., Blumberg, B., Carroll, L., Colborn, T., Everett, L.G., Hansen, M., Landrigan, P.J., Lanphear, B.P., Mesnage, R., Vandenberg, L.N., Vom Saal, F.S., Welshons, W. V, Benbrook, C.M., 2016. Concerns over use of glyphosate-based herbicides and risks associated with exposures: a consensus statement. Environ. Heal. 15. https://doi.org/10.1186/s12940-016-0117-0

Nikkila, A., Paulsson, M., Almgren, K., Blanck, H., Kukkonen, J.V.., 2001. Atrazine Uptake , Elimination , and Bioconcentration By Periphyton Communities and Daphnia Magna $\square$ : Effects of Dissolved Organic Carbon. Environ. Toxicol. Chem. 20, 1003-1011.

Paganelli, A., Gnazzo, V., Acosta, H., López, S.L., Carrasco, A.E., 2010. Glyphosate-Based Herbicides Produce Teratogenic Effects on Vertebrates by Impairing Retinoic Acid Signaling. Chem Res Toxicol 23, 1586-1595. https://doi.org/10.1021/tx1001749

Pérez, D.J., Okada, E., Menone, M.L., Costa, J.L., 2017. Can an aquatic macrophyte bioaccumulate glyphosate? Development of a new method of glyphosate extraction in Ludwigia peploides and watershed scale validation. Chemosphere 185, 975-982. https://doi.org/10.1016/j.chemosphere.2017.07.093

Pérez, G.L., Torremorell, A., Mugni, H., Rodríguez, P., Vera, M.S., Do Nascimento, M., Allende, L., Bustingorry, J., Escaray, R., Ferraro, M., Izaguirre, I., Pizarro, H., Bonetto, C., Morris, D.P., Zagarese, H., Perez, G.L., Rodriguez, P., Do Na, M., Allende, L.:, Donald, C., Morris, P., Zagarese1, H., 2007. Effects of the Herbicide Roundup on Freshwater Microbial Communities: A 
Beecraft and Rooney. 2020. Bioconcentration of glyphosate in wetland biofilms. PREPRINT. Contact rrooney@uwaterloo.ca

Mesocosm Study. Ecol. Appl. 17, 2310-2322.

Peruzzo, P.J., Porta, A.A., Ronco, A.E., 2008. Levels of glyphosate in surface waters, sediments and soils associated with direct sowing soybean cultivation in north pampasic region of Argentina. Environ. Pollut. https://doi.org/10.1016/j.envpol.2008.01.015

Pizarro, H., Vera, M.S., Vinocur, \& A., Pérez, G.L., Ferraro, \& M., Menéndez Helman, R.J., Dos, \& M., Afonso, S., 2016. Glyphosate input modifies microbial community structure in clear and turbid freshwater systems. Environ. Sci. Pollut. Res. 23, 5143-5153. https://doi.org/10.1007/s11356-015$5748-0$

R Core Team, 2020. R: A language and environment for statistical computing.

Relyea, R.A., Jones, D.K., 2009. the Toxicity of Roundup Original Max ${ }^{\circledR}$ To 13 Species of Larval Amphibians. Environ. Toxicol. Chem. 28, 2004. https://doi.org/10.1897/09-021.1

Reno, U., Gutierrez, M.F., Regaldo, L., Gagneten, A.M., 2014. The Impact of Eskoba®, a Glyphosate

Robichaud, C.D., Rooney, R.C., n.d. Glyphosate used to control invasive Phragmites australis in standing

Robinson, D., Hayes, A., 2020. broom: Convert StatisticalAnalysis Objects into Tidy Tibbles. Environ. 702, 134472. https://doi.org/10.1016/j.scitotenv.2019.134472

Sabater, S., Guasch, H., Romaní, A., Muñoz, I., 2002. The effect of biological factors on the efficiency of river biofilms in improving water quality. Hydrobiologia 469, 149-156. 
Beecraft and Rooney. 2020. Bioconcentration of glyphosate in wetland biofilms. PREPRINT. Contact rrooney@uwaterloo.ca

750

751

752

753

754

755

756

Siemering, G.S., Hayworth, J.D., Greenfield, B.K., 2008. Assessment of Potential Aquatic Herbicide Impacts to California Aquatic Ecosystems. Arch Env. Contam Toxicol 55, 415-431. https://doi.org/10.1007/s00244-008-9137-2

Silva, V., Montanarella, L., Jones, A., Fernández-Ugalde, O., Mol, H.G.J., Ritsema, C.J., Geissen, V., 2018. Distribution of glyphosate and aminomethylphosphonic acid (AMPA) in agricultural topsoils of the European Union. Sci. Total Environ. 621, 1352-1359. https://doi.org/10.1016/j.scitotenv.2017.10.093

Smedbol, É., Gomes, M.P., Paquet, S., Labrecque, M., Lepage, L., Lucotte, M., Juneau, P., 2018. Effects of low concentrations of glyphosate-based herbicide factor $540 \AA$ on an agricultural stream freshwater phytoplankton community. Chemosphere 192, 133-141. https://doi.org/10.1016/j.chemosphere.2017.10.128

Smedbol, É., Lucotte, M., Labrecque, M., Lepage, L., Juneau, P., 2017. Phytoplankton growth and PSII efficiency sensitivity to a glyphosate-based herbicide (Factor 540®). Aquat. Toxicol. 192, 265-273. https://doi.org/10.1016/J.AQUATOX.2017.09.021

Solomon, K., Thompson, D., 2003. Ecological Risk Assessment for Aquatic Organisms from Over-Water Uses of Glyphosate. J. Toxicol. Environ. Health 6, 289-324. https://doi.org/10.1080/10937400306468

Starcevic, A., Akthar, S., Dunlap, W.C., Shick, J.M., Hranueli, D., Cullum, J., Long, P.F., 2008. Enzymes of the shikimic acid pathway encoded in the genome of a basal metazoan, Nematostella vectensis, have microbial origins. PNAS Proc. Natl. Acad. Sci. United States Am. 105, 2533-2537.

Struger, J., Stempvoort, D.R. Van, Brown, S.J., 2015. Sources of aminomethylphosphonic acid (AMPA) in urban and rural catchments in Ontario, Canada: Glyphosate or phosphonates in wastewater? Environ. Pollut. 204, 289-297. https://doi.org/10.1016/j.envpol.2015.03.038 
Beecraft and Rooney. 2020. Bioconcentration of glyphosate in wetland biofilms. PREPRINT. Contact rrooney@uwaterloo.ca

Sutherland, I.W., 2001. Biofilm exopolysaccharides $\square$ : a strong and sticky framework. Microbiology 147, 3-9.

Sviridov, A. V., Shushkova, T. V., Ermakova, I.T., Ivanova, E. V., Epiktetov, D.O., Leontievsky, A.A., 2015. Microbial degradation of glyphosate herbicides (Review). Appl. Biochem. Microbiol. 51, 188-195. https://doi.org/10.1134/S0003683815020209

Tiam, S.K., Laviale, M., Feurtet-Mazel, A., Jan, G., Gonzalez, P., Mazzella, N., Morin, S., 2015. Herbicide toxicity on river biofilms assessed by pulse amplitude modulated (PAM) fluorometry. Aquat. Toxicol. 165, 160-171. https://doi.org/10.1016/j.aquatox.2015.05.001

Tsui, M.T.K., Chu, L.M., 2003. Aquatic toxicity of glyphosate-based formulations: comparison between different organisms and the effects of environmental factors. Chemosphere 52, 1189-1197. https://doi.org/10.1016/S0045-6535(03)00306-0

Vera, M.S., Lagomarsino, L., Sylvester, M., Pérez, G.L., Rodríguez, P., Mugni, H., Sinistro, R., Ferraro, M., Bonetto, C., Zagarese, H., Pizarro, H., 2010. New evidences of Roundup (R) (glyphosate formulation) impact on the periphyton community and the water quality of freshwater ecosystems. Ecotoxicology 19, 710-721. https://doi.org/10.1007/s10646-009-0446-7

Walz GmbH, H., 1998. Underwater Fluorometer Diving-PAM. Handbook of Operation.

Wang, C., Lin, X., Li, L., Lin, S., 2016. Differential Growth Responses of Marine Phytoplankton to Herbicide Glyphosate. PLoS One 11, e0151633.

Wang, H., Kostel, J.A., St. Amand, A.L., Gray, K.A., 1999. 2. The response of a laboratory stream system to PCB exposure: study of periphytic and sediment accumulation patterns. Water Res. 33, 37493761. https://doi.org/10.1016/S0043-1354(99)00126-8

Wang, S., Seiwert, B., Miltner, A., Sch, A., Reemtsma, T., Yang, Q., Nowak, K.M., 2016.

(Bio)degradation of glyphosate in water-sediment microcosms e A stable isotope co-labeling 
Beecraft and Rooney. 2020. Bioconcentration of glyphosate in wetland biofilms. PREPRINT. Contact rrooney@uwaterloo.ca

approach. Water Res. 99, 91-100. https://doi.org/10.1016/j.watres.2016.04.041

797 Wickham, H., Averick, M., Bryan, J., Chang, W., D’, L., Mcgowan, A., François, R., Grolemund, G., Hayes, A., Henry, L., Hester, J., Kuhn, M., Lin Pedersen, T., Miller, E., Bache, S.M., Müller, K., Ooms, J., Robinson, D., Seidel, D.P., Spinu, V., Takahashi, K., Vaughan, D., Wilke, C., Woo, K., Yutani, H., 2019. Welcome to the Tidyverse. J. Open Source Softw. 4, 1686. https://doi.org/10.21105/joss.01686 


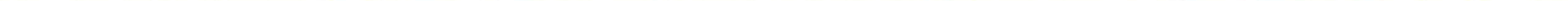

